\title{
Reversing History?: The Challenges of Using "MABO No. 2" as an Avatar for Resolving Indigenous Land Claims in Africa
}

\author{
Ernest Duga Titanji \\ Faculty of Laws and Political Science, University of Yaoundé II, Yaoundé, Cameroon \\ Email: ernestdugatitanji@gmail.com
}

How to cite this paper: Titanji, E. D. (2020). Reversing History?: The Challenges of Using "MABO No. 2" as an Avatar for Resolving Indigenous Land Claims in Africa. Beijing Law Review, 11, 690-708. https://doi.org/10.4236/blr.2020.113042

Received: June 19, 2020

Accepted: September 7, 2020

Published: September 10, 2020

Copyright (๑) 2020 by author(s) and Scientific Research Publishing Inc. This work is licensed under the Creative Commons Attribution International License (CC BY 4.0).

http://creativecommons.org/licenses/by/4.0/

\section{(c) (i) Open Access}

\begin{abstract}
The nexus between the indigenous African and the land on which they live cannot be gainsaid. So important is this relationship that land is a sine qua non for the survival of the indigenous African and indigenous African cultures. However, despite this undisputed link, the indigenous African as well as other colonized peoples, lost ownership of their lands due mainly to the adverse effects of subjugation. The direct upshot of this is that even where the former colonial masters and their successor states have become sympathetic to the indigenous populations and decide to retrocede some of their land, they often encounter obstacles both in law and in modern history that are not easy to avoid. This was also the case in some countries where indigenous peoples lost their lands to settlers who took over command and decided on their destiny, such as the indigenous peoples in Australia. It was in an attempt to put this issue to rest that the High Court of Australia in the locus classicus MABO No. 2 attempted to define the circumstances under which land can revert to the indigenous populations as a matter of human rights. This article examines some of the "hooks" that the apparently generous MABO No. 2 decision may present, where there is an attempt to transpose it mutatis mutandis as an avatar to resolve the problem of indigenous land rights in Africa. The paper attempts to answer the question as to what extent the decision of the High Court of Australia in MABO No. 2 can be used to resolve indigenous land claims in Africa. Through an analytical approach, the paper investigates the challenges inherent in attempting to use the decision as a South-South mutual inspiration due to the contextual, historical and evolutionary differences between the Australian and African situations. The paper finds out that the decision in MABO No. 2 carries in it the very germ of its inapplicability in the African context and makes suggestions on how to read the MABO decision in the context of the present-day dispensation of indigenous African land law.
\end{abstract}




\section{Keywords}

Human Rights, Terra Nullius, Indigenous Land Rights, African Land Law, South-South Cooperation

\section{Introduction}

It is now generally accepted that land and its resources are important to the survival of indigenous cultures, and by implication indigenous peoples ${ }^{1}$. Indigenous peoples have often articulated ideas of communal stewardship over land and a deeply felt spiritual and emotional nexus with the earth and its fruits ${ }^{2}$. Indigenous peoples, furthermore, typically have looked to a secure land and natural resource base to ensure the economic viability and development of their communities ${ }^{3}$.

Many indigenous and tribal peoples have a special relationship to land. It is where they live, and have lived for generations. In many cases, their traditional knowledge and oral histories are connected to the land. Land to the indigenous African is considered sacred and full of spiritual meaning, and forms the very basis of their belonging. The whole concept of land and its importance to the indigenous African are most aptly summarized by this oft-quoted submission by a Nigerian chief to the West African Land Commission in 1912: "I conceive that land belongs to a vast family, of which many are dead, few are living and countless yet unborn" 4 .

Despite the importance of land to indigenous African culture and development as highlighted above, Africa happens to be one of the continents where indigenous land rights are least protected.

The African continent from the $17^{\text {th }}$ to the $19^{\text {th }}$ centuries, witnessed a series of events that led to the partition of the existing empires that formed Africa and to the subjugation of its peoples under colonial rule. The first Europeans who arrived laid claims on their lands, overpowered their political institutions and disrupted the integrity of their economies and cultures ${ }^{5}$.

The subjugation of the indigenous African was done in three ways: by conquest, by treaty or by the now infamous terra nullius (that is, by declaring that the land was vacant and hence was neither owned nor inhabited). These conditions existed in isolation but in some cases all three were united. According to

${ }^{1}$ See generally J.S Anaya (1996). Indigenous Peoples in International Law, Oxford University Press, $2^{\text {nd }}$ Edition.

${ }^{2}$ T.C McLuhan (ed.) (1971). Touch the Earth: A Self Portrait of Indian Existence; A compilation of Indigenous Peoples Statements about the Land and its Meaning.

${ }^{3}$ Supra (note 1 above).

${ }^{4}$ T.O Elias (1970). The Nature of African Customary Law at p. 162 cited in Report and Recommendations by the Panel of Experts on the Development of Policy Regarding Land Ownership by Foreigners in South Africa at p.6. Available at http://www.pmg.org.za/files/gazettes/070914land-panelreport.pdf (accessed 7 November 2014). ${ }^{5}$ Supra (note 1 above). 
Robert A. Williams, Jr. ${ }^{6}$, all three forms had one main consequence-that was the seizure of the land of the local inhabitants and this was done by the application of the most venerated principle of terra nullius. Under this doctrine, empty, unsettled or unpopulated land could be claimed by anyone who would settle and develop it. South Africa and Australia have been the champions of this doctrine. Again, this doctrine is culturally arrogant in that it presupposes that land which is not developed or used as a European would use it is undeveloped or unpopulated ${ }^{7}$.

The situation of land ownership of the Indigenous African now forms the subject of academic discourse in law, history, and anthropology both internationally and in the contexts of the states within which they find themselves today.

The same academic discourse had been entertained in other areas where indigenous peoples suffered similar injustices as a result of the deprivation of their access to their land. In Australia for example, the series of petitions culminated in 1992 in what is now known as the decision in MABO No. $2^{8}$ where the High Court of Australia preferred the doctrine of "aboriginal rights" to the doctrine of terra nullius.

The decision in MABO, on its face can be presented as a model of multiculturalism that can be exported to African countries in their quest to resolve their indigenous land issues. However, an in-depth reading of MABO immediately betrays its stance as an extension of cultural imperialism and "legal alterity" in the expansion of the common law as opposed to indigenous culture. For as Elizabeth Povinelli puts it, the new legal models of the multicultural nation and its citizenry have not displaced the classic liberal models of the state and citizenship, and the older models of citizenship continue to inform state function, public discourse, and individual feelings about what is right and wrong to demand from the state and its normative publics ${ }^{10}$.

The problem of restoring land to those indigenous peoples who now live as strangers on their own land has become increasingly topical especially with the recognition of those rights by the international community by the adoption of the Declaration of the Rights of Indigenous Peoples by the UN General Assembly in $2007^{11}$.

${ }^{6}$ R.A. Williams (1990). The American Indian in western legal thought, Oxford University Press. ${ }^{7}$ See A.M. Gibson (1984). "Philosophical, Legal, and Social Rationales for Appropriating the Tribal Estate, 1607 to 1980", 12 American Indian Law Review p.3.

${ }^{8}$ MABO and Others $v$ Queensland (No. 2) [1992] HCA 23; (1992) 175 CLR.

${ }^{9} \mathrm{E}$. Povinelli (2002). The cunning of recognition: Indigenous alterities and the making of Australian culturalism, Duke University Press.

${ }^{10}$ See Supra (note 9 above) at p. 185. "These new legal models of the multicultural nation and its citizenry have not displaced classic liberal models of the state and citizenship, nor do many state and public spokespersons intend them to. These older models of citizenship continue to inform state function, public discourse, and individual feelings about what is right and wrong to demand from the state and its normative publics".

${ }^{11}$ Declaration of the Rights of Indigenous Peoples, adopted by the UN General Assembly at its $107^{\text {th }}$ plenary meeting on 13 September 2007. Available at

http://www.un.org/esa/socdev/unpfii/documents/DRIPS_en.pdf (accessed 11 December 2014). 
Rights are most aptly recognized by a combination of all the aspects of positive law $^{12}$. These are, the existence of legislation which in this case includes international treaties, customs derived from the way of life of the people, and case law which constitutes decisions handed down by the courts. Australia happens to be one of the countries where a congruence of all these three factors has afforded some form of rights to its indigenous peoples. Povinelli justifies this by stating that it was the juridical struggle to formulate a legally valid multicultural form of common law that provided a particularly important perspective on late liberal forms of power and that:

Legal decisions bring into sharp relief the disjunction between ideologies of recognition and the practices and pragmatics of the distribution of right, materials, and institutions ${ }^{13}$.

As the law is the greatest instrument of social change ${ }^{14}$, so too, it is a dangerous weapon in the hands of the most erudite judges who can play with words and coin an obscurantist perception of an idealist regime where the direct opposite of what is sought to be achieved is actually what is offered. For "the law is a significant site where local languages are diverted into juridical languages, atrophying imaginations of alternative forms of collective action" ${ }^{15}$. MABO happens to be one such instance and if not read meticulously can mislead in its verbiage as opposed to its underlying meaning.

This paper examines the possible challenges one may face in advocating for the use of the MABO decision as inspiration to resolve indigenous land claims in the African context.

This paper is limited to answering the question to what extent the decision of the High Court of Australia in MABO No. 2 can be used to resolve indigenous land claims in Africa. It does not dwell on investigating such things as the meaning of who is indigenous to Africa (which is the subject of a whole research of its own). This paper contents itself with assuming that when mention is made of the "Indigenous African" this means native African, bearing in mind the fact that there has been substantial movements even within local communities that at times it becomes difficult to determine which native African is indigenous to the land and which one is not. Secondly, the history of how the different indigenous groups lost their land (which again is the subject of a whole historical investigation of its own) is not dwelt on. Thirdly, and finally the paper does not seek to investigate into the anthropological and spiritual significance of land to the indigenous African. It is assumed that significance is established by unchallenged existing literature.

\section{MABO No. 2 (Brief Facts and Rationale)}

In the MABO case, the Meriam people (represented by a certain MABO)

${ }^{12}$ Customs, Legislation, and Case Law.

${ }^{13}$ Supra (note 9 above) at p. 184.

${ }^{14}$ See generally W.G Sumner (1906). Law and Social Change, Folkways New York and J. Stone (1966) Social Dimensions of Law and Justice, London, Stevens.

${ }^{15}$ Supra (note 9 above) at p.184. 
claimed continuous connection with their land. This was despite the fact it had been declared a possession of the New South Wales Colony in 1797 and then annexed by the Queensland government in 1879. The Queensland government said it had saved the Indigenous people of the Murray Islands from "barbarism" and that the Crown had assumed all rights to the land in 1879. This assertion, however, was undermined by the fact that in 1913 the Queensland government had bought land from the Meriam people on which to build a police station.

On 3 June 1992 six of the seven High Court Judges ruled that: "The Meriam people are entitled as against the whole world, to possession, occupation, use and enjoyment of the lands of the Murray Islands".

The MABO judgment declared that terra nullius had never legally existed and that it had been wrongfully applied to Australia. The high court stated that "ultimate" title existed instead, and through that, native title could be claimed. Australian land law has developed from English land law and it was under those principles that Australia was settled. At common law all land is owned by the Crown, which then deals with that land as it sees fit.

The court in $\mathrm{MABO}$ found that Aboriginal Australians retained their native title interests in land if they retained the traditional customs, beliefs, and practices that created the substance of their difference and if these customs were not repugnant to equity, natural justice and good conscience ${ }^{16}$.

\section{Applying MABO to Resolve Indigenous Land Claims in Africa: South-South Mutual Inspiration}

Many African legal scholars will recall that their pattern of studies and legal thought in general have been shaped by some western line of thought. Not only were laws and legal systems transplanted into Africa with colonialism, but also the new elite class of African lawyers was trained to maintain and keep these systems running.

With the rise of multiculturalism, this trend is being reversed. A new breed of scholarship is developing, challenging the generally held view that all that comes from the West is good and nothing that comes from the "global south" is good" ${ }^{17}$.

In this global movement, Duncan Kennedy sees three global movements of the law ${ }^{18 .}$ The first globalization or that which corresponds to the period between 1850 and 1914 was marked by classical legal thought (CLT). The second period between 1900 and 1968 was marked by what he calls social globalization, which to him is a way of thinking without an essence. That period was pre-occupied with rethinking law as a regulatory mechanism that could and should facilitate

${ }^{16}$ Supra (note 9 above) at pp.163-164.

${ }^{17}$ “'The 'Global South' has become shorthand for the world of non-European, post-colonial peoples. Synonymous with uncertain development, unorthodox economies, failed states, and nations fraught with corruption, incivility, strife etc ..." Jean Comaroff and John Comaroff (2012). The theory from the South: Or how Euro-America is evolving toward Africa, Paradigm Publishers.

${ }^{18}$ D. Kennedy; “Three Globalizations of law and Legal Thought: 1850-2000", in D.M Trubek and A. Santos (eds) 2006. The New Law and Economic Development. A Critical Appraisal New York: Cambridge University Press, pp. 19-73. 
the evolution of social life with an ever-greater social interdependence at all levels, from the family to the world of nations.

In the third globalization, in place of the Professor of CLT in the first globalization and the legislator/administrator in the social, the hero figure is the judge who brings either policy analysis or neoformalism to bear on disputes brought before him by governmental and non-governmental organizations claiming to represent civil society. In this model, according to Kennedy, human rights play the same role that "private rights" played in CLT and "social rights" in the social $^{19}$.

Kennedy sees some form of Unitedstatesean genealogy in the third globalization. He argues, however, that it will be an exaggeration to over amplify the Americanization of the third globalization as public law neoformalism has a European as well as a Unitedstatesean geneology ${ }^{20}$.

It is the role of judges as highlighted in Kennedy's third generation that will be used as a strong argument to make the case for applying the MABO case in the African context.

The solution to the resolution of issues relating to indigenous African land claims will not come from the North. Inspiration can come from the south. Jean and John Comaroff ${ }^{21}$ argue that theory developed in the "global south" can also be used in a positive way to resolve issues of the south and not only reliance on theories from the "global north". To them, the epistemic scaffolding on which western enlightenment thought is built can be reversed and they argue that, "at the present moment it is the global South that affords privileged insight into the workings of the world at large"22.

Based on these two foundations, it is submitted that the decision in MABO can be applied to resolve indigenous land claims in Africa as no perfect inspiration can come from the Global North which will insist on the application of the principles of the common law as they stand today.

But MABO cannot be applied mutatis mutandis to Africa. In the next part the reasons why a direct application of MABO may not be possible are examined.

\section{MABO's Hooks}

This part examines some of the challenges that an attempt at transposing the decision in the MABO case to African countries might encounter. The decision in MABO itself as an exportable model carries the germ that will infect its fruits if exported to be applied to resolve indigenous land issues in most African countries. There is an important proviso in the decision which if closely read negates the good will that can be attributed to the judgment.

[The] people [must] have maintained their connection with the land through the years of European settlement, and where their title has not been extinguished ${ }^{19}$ Supra (note 18 above) at p. 65.

${ }^{20}$ Supra (note 18 above) at p. 67.

${ }^{21}$ Jean Comaroff and John Comaroff (2012). The theory from the South: Or how Euro-America is evolving toward Africa, Paradigm Publishers.

${ }^{22}$ Supra (note 21 above) at p. 1. 
by valid acts of Imperial, Colonial, State, Territory or Commonwealth Governments.

It is important to look at these two limiting factors and in the ensuing lines before analysing the difficulties inherent in attempting to apply them in the African context.

\section{The Limiting Factors in the MABO Decision}

The decision in the MABO case fixes two condition-precedents for the court to entertain a matter from "a people" who seek to reverse the ownership of land acquired through the operation of the terra nullius principle and recognize indigenous or aboriginal land ownership, namely:

1) That the people must have maintained their connection with the land through the years of European settlement; and

2) That their title must not have been extinguished by valid acts of Imperial, Colonial, State, Territory or Commonwealth Governments.

\subsection{Must Have Maintained Their Connection with the Land through the Years of European Settlement}

This condition touches on the substratum of the terra nullius doctrine. The point made by the court seems to be that where connection was not maintained with the land throughout the period of European settlement, then the land belongs to Europeans-Vacans terram, terra universalis Europa.

The High court justified this position in the following words: “... when the tide of history has washed away any real acknowledgement of traditional law and any real observance of traditional customs ${ }^{23}$ the foundation of native title disappeared and native title rights were extinguished.

Paul Keating, the Australian Prime Minister at the time, summarized his understanding of the MABO decision by stating that the Court accepted the existence of native title where two fundamental conditions were met namely that the connection with the land had never been broken and that the title had never been overturned by any action of government ${ }^{24}$.

The first part of this statement relates directly to the first point under discussion-continued maintenance of their link with the land through European occupation. This raises a major problem.

The main purpose of colonial incursion on indigenous land was to dispossess indigenous peoples of their lands. To expect them to have maintained some link, however slim or even transient with the land to say the least is an aberration. How could the land at the same time be declared terra nullius and at the same ${ }^{23}$ Supra (note 8 above).

${ }^{24}$ P.J. Keating (1994). "Prime Minister's Address to the Nation” in M. Goot and T. Rouse (eds) Make a Better Offer. The Politics of MABO Leichhardt, NSW: Pluto Press, at p. 236.

"The Court accepted that native title existed where two fundamental conditions were met: that their connection with the land had been maintained unbroken down through the years, and, that this title had not been overturned by any action of a government to use the land or to give it to somebody else". 
time occupied by the indigenous owners?

Povinelli ponders if "these limits [should be read] as simply rhetorical, minor moments in a major judgment, or as an essential discursive architecture of multiculturalism?" ${ }^{25}$

Jacob Dlamini ${ }^{26}$ paints a very pathetic picture in the context of South Africa where the indigenous African was not even allowed to buy land under the apartheid regime unless he was able to show his link with the particular piece of land in question.

The Australian High Court itself would come to discover how much it had entangled itself in unnecessary juridism just a few years after MABO in its decision in The Members of the Yorta Yorta Aboriginal Community v. the State of Victoria $^{27}$ where the court was faced with adjudicating in a field of judicial metaphors such as measuring cultural tides, their ebbs and their flows. Faced with this situation, the court could only arrive at the decision that the circumstances allowed it to find that the native title rights and interests of the Yorta Yorta had been extinguished through lack of maintenance of beliefs and practices giving these rights their content. According to Povinelli, "the Yorta Yorta suffered from the discomfort of the cultural uncanny in a multicultural state"28.

This case if decided under the international human rights framework of indigenous peoples may receive a different decision in the light of the case of Sandra Lovelace v. Canada ${ }^{29}$, in which the author of the communication that was dated 29 December 1977 and supplemented by letters of 17 April 1978, 28 November 1979 and 20 June 1980, was a 32-year-old woman, living in Canada. She was born and registered as "Maliseet Indian" but had lost her rights and status as an Indian in accordance with section 12 (1) (b) of the Indian Act, after having married a non-Indian on 23 May 1970. Pointing out that an Indian man who marries a non-Indian woman does not lose his Indian status, she claimed that the Act was discriminatory on the grounds of sex and contrary to articles 2 (1), 3, 23 (1) and (4), 26 and 27 of the Covenant.

By its decision of 14 August 1979, the Human Rights Committee declared the communication admissible even though at that time no information or observations had been received from the State party concerning the question of admissibility of the communication.

Hence the question of permanent and continued connection with the land and the loss of such connection thereof should not constitute a ground on which one may be declared to have lost his right as an indigenous person to land which hitherto belonged to his forefathers.

On the strength of the foregoing therefore, one is tempted to argue that the decision adds nothing to reverse the terra nullius doctrine but rather comforts ${ }^{25}$ Supra (note 9 above) at p. 164.

26"The Organic Native? Reframing the Land Question in South Africa" Unpublished manuscript.

${ }^{27}$ Members of the Yorta Yorta Aboriginal Community v Victoria \& Ors [1998] FCA 1606 (18 December 1998).

${ }^{28}$ Supra (note 9 above) at p. 165.

${ }^{29}$ Communication No. R.6/24 (29 December 1977), U.N. Doc. Supp. No. 40 (A/36/40) at 166 (1981). 
the position of the settlers where no indigenous presence can be demonstrated.

\subsection{Their Title Has Not Been Extinguished by Valid Acts of Imperial, Colonial, State, Territory or Commonwealth Governments}

This is also another problematic proviso in the decision. This poses the problem of indigenous land ownership within states that are successors to colonial regimes. The argument here is that where there were "valid acts", those valid acts will take precedence over indigenous land rights. This was the second arm of Prime Minister Keating's statement: "and that this title had not been overturned by any action of a government to use the land or to give it to somebody else"30. This provision is pregnant with injustice and only goes a long way to serve the extension of imperialism. In this part, what may be termed "valid acts" is looked at.

Most African states today are post-colonial states with indigenous peoples caught in the entrails of what is left by the colonial masters to the successor state. Their forefathers had lost their lands by some act of the colonial master that had nothing to do with their consent and no reference was made to their existence when the colonial masters left.

Achille Mbembe argues that the State in Sub-Sahara Africa was never more than a structure imposed by violence on societies not only external to it but hostile to it and that a large number of communities with highly dispersed power structures did have their first experience of state in the colonial context ${ }^{31}$. It is this same power that for the most time was translated and transmitted to the successor states.

In order to examine the "valid acts" component, it will be germane to revisit on the one hand how valid the acts could be said to be before analysing how fair the so-called "valid acts" were to the indigenous African.

\subsubsection{The Validity of the So-Called "Valid Acts"}

The whole idea of "valid acts" suggests that any act emanating from the colonial master was a "valid act". In the same line of reasoning, one may argue that the proposition seems to suggest that the whole idea of colonialism itself was a valid act (whether it was done by application of the terra nullius principle or by brutal conquest and dispossession of the native African of their land). Povinelli describes one such act (the Aboriginal Ordinance of 1911) which is now noted for producing a large portion of what is referred to as the "Stolen Generation of Australians"32 where the High Court when seised of deciding the constitutionality of such a law ruled that although "Territory law had authorized gross viola-

\footnotetext{
${ }^{30}$ Supra (note 24 above).

${ }^{31}$ A. Mbembe (2001). On the Post Colony University of California Press.

${ }^{32}$ Between 1910-1970, many Indigenous children were forcibly removed from their families as a result of various government policies. The generations of children removed under these policies became known as the Stolen Generations. The policies of child removal left a legacy of trauma and loss that continues to affect Indigenous communities, families and individuals. Source: http://www.australianstogether.org.au/stories/detail/the-stolen-generations (accessed 20 May 2015).
} 
tions of the rights and liberties of Aboriginal Australians, these gross violations did not abrogate any constitutionally recognized rights and duties" ${ }^{33}$. How can it then be argued on the face of this, that any colonial act could have been declared as invalid by any court and who would have had the locus standi to bring such an action?

Using the cultural argument of non-repugnancy to natural justice, equity, and good conscience, the colonial authorities were the only ones competent to judge the validity of an act. Thus, all colonial acts were valid acts and any act of the indigenous native that could conveniently create a link with their land would be declared not to be a valid act and hence invalidate ownership.

Such a conclusion, if applied today will amount to forfeiture of indigenous land on grounds of a so-called "valid act" by the colonial master, which act itself may not be fair on the one hand, nor valid, on the other hand.

\subsubsection{The Fairness of Treaties with African Entities during the Colonial Period}

Here a analysis is attempted of how fair the treaties could have been, taking into consideration the level of education of the Africans at the time and if those treaties can be set aside under the present dispensation.

The history of treaties between African States and their colonizers can be traced back to the aftermath of the Berlin Colonial Conference ${ }^{34}$. When it became evident that ownership of colonies in Africa was a symbol of strength and recognition in Europe, those European states that had links with African States decided to consolidate the relationship and some who did not, joined the scramble to gain land in Africa. However, since the conference was held in Berlin far from Africa, the only way that these European states could justify their presence in any particular part of Africa was to produce an agreement (treaty) signed with the local chief of that territory.

On its face the Berlin Act sought to achieve inter alia two fundamental issues $^{35}$ :

1) The Principle of Notification (Notifying) other powers of a territorial annexation; and

2) The Principle of Effective Occupation to validate the annexations.

Meanwhile to the Africans the treaties were mere diplomatic and commercial treaties, the Europeans were subsequently going to treat them as though the Africans had transferred sovereignty over their land to them ${ }^{36}$. Through this the

${ }^{34}$ Berlin West Africa Conference, also known as the Congo Conference, 1884-85. Available at http://www.britannica.com/EBchecked/topic/62214/Berlin-West-Africa-Conference (accessed on 20 May 2015).

${ }^{35}$ The other issues can be summarized as freedom of trade in the Congo basin, a declaration relative to slave trade, a declaration relative to the neutrality of the territories, an act of navigation for the Congo, and an act of navigation for the Niger.

${ }^{36}$ The Principle of Effective Occupation did not apply so much to the hinterlands of Africa at the time of the conference. This gave rise to "hinterland theory", which basically gave any colonial power with coastal territory the right to claim political influence over an indefinite amount of inland territory.
} 
Europeans would rule the African colonies through different mechanisms ${ }^{37}$ with the most significant ${ }^{38}$ factor being that the European powers could legislate in the colonies. Policy decisions were taken in Europe far from the area concerned and colonial legislation took primacy over local laws and customs.

Laws were to be passed banning certain African customs and practices and in order for a custom or practice to be recognized, it had to respect European norms, customs, and must not be "repugnant to equity, natural justice, and good conscience" ${ }^{\prime 39}$.

It was in this backdrop that land tenure laws were enacted. While it is arguable that those laws were initially intended to protect inter-imperialist interests, one cannot hesitate to wonder if the laws that emanated from those treaties could be fair to the native African. If they were not fair to the native African, how then can it be stated that for indigenous rights to be recognized, "this title [must] not [have] been overturned by any action of a government to use the land or to give it to somebody else" ${ }^{30}$.

The land tenure laws were for European interests and supported grabbing land from indigenous communities for various reasons including the creation of plantations to provide for European needs ${ }^{41}$. Consonant with this, it can safely be stated that the agreements were not fair to indigenous peoples and hence cannot form a basis for the appraisal of their ownership of the land or better still cannot be used to justify the loss of such land by the indigenous communities.

\section{The Validity of Colonial and Successor State Pieces of Legislation}

The whole argument on recovering indigenous land is based on their loss as a result of colonialism. When colonialism ended, the land reverted to successor governments which continued managing the land in the same way the colonial masters did. In this connection, three issues are discussed in this part:

- The legality and legitimacy of the so-called "valid acts".

- The situation where the "valid acts" have themselves changed with the colonial masters as in the case of Cameroon (from the Germans, to the British and French, to the Federal State with different federal laws and then to the Unitary state with one body of laws). Which of these laws are valid when the one contradicts the other?

\footnotetext{
${ }^{37}$ The British governed through the famous "indirect rule", the French through "le principe d'assimilation" (or direct rule whereby the colony and its people were simply assimilated into France.

${ }^{38}$ For this paper because it is discussing the influence of legislation or Imperialist Acts.

${ }^{39}$ See for example Section 27 (1) of the Southern Cameroons High Court Law, 1955: "The High Court shall observe, and enforce the observance of, every native law and custom which is not repugnant to natural justice, equity, and good conscience, nor incompatible either directly or by implication with any law for the time being in force, ..."

${ }^{40}$ Supra (note 24 above).

${ }^{41}$ In Cameroon for example, the Germans created reservaats and created two companies (the South Cameroon company and the North West Cameroon company) that controlled over 0ne-fifth of the land in Kamerun. These subsequently became the Cameroon Development Corporation after independence.
} 
- The situation where the land has been used for common interest projects but without compensation to the indigenous groups that in some cases may have forgotten about the land.

\subsection{The Legality and Legitimacy of the So-Called "Valid Acts"}

The question of the legality of the so-called "valid acts" has been slightly addressed. As a question of law, a treaty is only valid if it is signed by the constitutional rights holder (or his designated representative) and for it to become law, it must be ratified through whatever procedure is prescribed by the Constitution of that state. It has been argued that none of those treaties conformed to this basic international law requirement. In fact, it is even stated that when the Africans realised they had been defrauded, they organised military action to challenge their European counterparts: "After discovering that they had in effect been defrauded and that the European powers now wanted to impose and exercise political authority in their lands, African rulers organized militarily to resist the seizure of their lands and the imposition of colonial domination" ${ }^{32}$.

It flows from the foregoing that the treaties that were fraudulently squeezed out of the African Chiefs were illegal and as a consequence, all acts emanating from them were also illegal. Once illegality has been established, it only goes without saying that the subsequent acts (legislation, judicial decisions etc.) that followed could not achieve any legitimacy since those who issued them did not themselves enjoy the legitimacy to carry out such acts.

\subsection{The Situation Where the "Valid Acts" Have Themselves Changed with the Colonial Masters over Time}

There are instances where the colonial acts did change over time. There are two clear scenarios here. The first is where the colonial masters themselves over time changed the colonial "act" thereby blurring the link between the indigenous peoples and their land. For instance, an indigenous community could be moved from their land by a colonial Act and the land used for agricultural or plantation purposes (with a new community settling and living on that piece of land as the new owners) and then the land is subsequently transferred for mining purposes (causing the new inhabitants to move). Several decades (and centuries after), it becomes difficult to tell the rightful, original or indigenous owners of the land. Also, the original indigenous owners who now own another piece of land, which may not be theirs, may want to lay claim onto that piece of land. This may create a spiral of uncertainties.

The second is where the colonial masters themselves changed and the new colonial masters introduced new acts to consolidate their position. A glaring example of this is the situation of Cameroon. Cameroon has the peculiarity of hav-

${ }^{42}$ E.G Ehiedu Iweriebor, The Colonization of Africa, Schomburg Center for research in Black Culture, New York, Available at

http://exhibitions.nypl.org/africanaage/essay-colonization-of-africa.html,

(accessed 14 December 2014). 
ing gone through three different colonial legacies with each one introducing their own land tenure system.

The first were the Germans when Cameroon was made a German Protectorate in 1884. The Germans introduced herrenlos ${ }^{43}$ by which all land that was not effectively occupied by natives was considered state land (in effect, as part of German Overseas Territory). Then when Germany was defeated during World War I, Cameroon was handed over to the British and the French as a mandated territory in July 1919. The French introduced the notion of "terre vacantes sans maittre" in their own part of the country claiming that all land not effectively occupied was vacant land and hence state land that they could (and in fact did) exploit without rendering account to any body. The British on their part subjected indigenous control and ownership of land to the control of the British Prime Minister who was deemed to hold and administer the land for the natives $^{44}$. Indigenous rights of ownership were simply transformed into customary rights of occupancy ${ }^{45}$.

In a nutshell, what is apparent here are two different colonial models operating in one country and when the country finally gained independence and decided to unify, it was faced with the challenge of which system to apply. The French system, which is more state-centric and less indigenous-rights friendly prevailed.

This, is aptly stated by Philip Burnham:

Under the British Colonial system of "Indirect Rule", 'vacant' lands were considered in the last instance (following the Land and Native Rights Ordinance of 1927) to belong to local communities-in the person of colonially created "native authorities". There was no corresponding notion of communal or 'native' lands in the francophone area, and when the two federated territories were unified in 1972, the British-inspired conception was scrapped in favour of the French one $e^{46}$.

Cameroon has since 1974 passed a series of land laws but none has digressed from the colonial position by returning the land to the rightful owners. In fact, attempts to recover land by indigenous groups have been very strongly opposed by the successor ${ }^{47}$ state governments ${ }^{48}$.

This presents laconically, one of the challenges which a direct application of MABO might encounter where succession lines have faded over time unintentionally and where several centuries after, it becomes impossible to reverse the so-called "valid acts" to accommodate the rights of indigenous peoples in suc${ }^{43}$ By the German Kronland Act of 15 July, 1896.

${ }^{44}$ Land and Native Rights Ordinance, 1927.

${ }^{45}$ Supra (note 44 above) Article 2.

46"Whose Forest? Whose Myth? Conceptualisation of Community Forests in Cameroon" (2000), in A. Abramson and D. Theodossopoulos (eds.) Land, Law and Environment. Mythical Land, Legai Boundaries Pluto Press.

${ }^{47}$ I use successor government here because the government in place in successor states merely continues with policies that were put in place by the colonial masters.

${ }^{48}$ See the Case of Bakweri Land Claims Committee (BLCC) v. Cameroon, Communication (2014) No 260/2002, ACHPR 16 ${ }^{\text {th }}$ Extraordinary session 20-29 July 2014. 
cessor colonial states.

\subsection{The Situation Where the Land Has Been Used for Common Interest Projects}

In several instances where the principle of terra nullius or terres vacante sans maitre or herrenlos was applied, this was done to appropriate large parcels of land from the indigenous peoples to create large plantations and industrial estates. It wasn't to seize a few hectares of land. The notion of common interest here may be misleading, as ultimately the land was not used in the interest of the indigenous peoples but for the interest of the colonizers. In any case, upon independence, the plantations returned to the successor states. The state in turn laid ownership over the land ${ }^{49}$.

The question which arises is that of determining to which indigenous group to return the land if the state decides to do so. It is difficult (if not impossible) to trace the spiritual or psychological link to the land which indigenous peoples use as their mantra to lay claim over the land.

The situation was exacerbated in some developing countries where under the impulse of International Financial Institutions ${ }^{50}$ certain states were forced to privatize state-owned enterprises ${ }^{51}$. In this privatization process the states did not revert to the original indigenous owners of the land but decided in reliance on the terra nullius principle that the land was state land and granted concessions to the purchasers in disregard of the rightful owners ${ }^{52}$.

This became very contentious in certain instances and it is now argued that the rights of the indigenous populations ought to have been taken into consideration. But consistent with "sub paragraph 2" above it becomes difficult to determine which indigenous category should be considered as the rightful owners of the land.

\section{Recommendations on the Interpretation of MABO in Line with Indigenous African Land Rights Claims}

\subsection{Towards an Introduction of General Indigenous Land Rights: Problems and Solutions (UN Declaration of the Rights of Indigenous Peoples, 2007)}

With the adoption of the UN Declaration of the Rights of Indigenous Peoples $(\mathrm{DRIP})^{53}$, there is now a proper international legal framework for the resolution

\footnotetext{
${ }^{49}$ The current Cameroon land legislation still holds that all land is state land. Plantations left since the German era are considered as state owned plantations.

${ }^{50} \mathrm{The}$ International Monetary Fund and the World Bank.

${ }^{51}$ For example, in Cameroon the "Cameroon Development Corporation" which was an off-spring of German colonialism and which was transferred to the State after independence was privatized without taking into consideration the interest of the indigenous peoples who were the rightful owners of the land. This led to the creation of what became known as the "Bakweri Land Claims Committee" to act as a pressure group to protect the rights of the indigenous Bakweris and lay claim over their ancestral lands.

${ }^{52}$ The situation of the indigenous Bakweris is mentioned above in note 48 .

${ }^{53}$ Adopted by the UN General Assembly on 13 September 2013.
} 
of claims relating to the ownership of indigenous lands. The DRIP clearly states that indigenous and tribal peoples have rights to the land they traditionally occupied: "Indigenous peoples have the right to the lands, territories and resources which they have traditionally owned, occupied or otherwise used or acquired"54.

But what are "lands which they have traditionally owned"? These, as has been argued throughout this paper, are lands where indigenous and tribal peoples have lived over time, and which they have used and managed according to their traditional practices. These are the lands of their ancestors, and which they hope to pass on to future generations. It might in some cases include lands which have been recently lost.

Thus, the first place to turn for an implementation of the rights of indigenous peoples would be to look at the provisions of the DRIP. But Article 26(1) of the declaration does not seem to resolve a critical issue raised in MABO and the existing literature on the issue. The declaration provides that the people shall have rights to the lands, territories, and resources, which they have traditionally owned, occupied or otherwise used or acquired. In order to avoid this hook, it is recommended to look beyond MABO as the Australian High Court itself did.

\subsection{Extend MABO beyond "Connection" and "Valid Acts"}

As mentioned earlier ${ }^{55}$, the decision in MABO carries the germ of its own destruction. After battling with the question of "connection to the land" in two decisions after $\mathrm{MABO}^{56}$, the Australian High Court was faced again with this situation in the case of the Wik People v. the State of Queensland $\phi^{77}$ where the court had to determine whether the granting of a pastoral lease necessarily extinguished native title.

In that case, the Wik peoples and the Thayorre people filed claims over large areas that included a number of pastoral leases, and two special mining leases granted under ratified State Government agreements. The claimants asserted that their native title rights had survived the grant of the pastoral leases, and that the mining leases were invalid. The respondents to the claim asserted that, applying the principles stated by the High Court in MABO, any native title that might have existed was necessarily extinguished by the grant of the pastoral leases. The Federal Court found against the claimants on both issues. On appeal to the Full Court of the Federal Court, the case was removed to the High Court. The High Court found for the claimants on the pastoral lease issue (by a majority of four judges to three), and found against them unanimously in relation to the special mining leases. 
The court was emphatic in its ruling that recognizing customary rights is not only an obligation but that customary rights constitute part of the common law:

Native title has its origin and is given its content by the traditional laws acknowledged by and the traditional customs observed by the indigenous inhabitants of a territory ... Native title, though recognized by common law, is not an institution of the common law and is not alienable by the common law. Its alienability is dependent on the laws from which it is derived.

And in a bold step to castigate even the powers of the common law court to contemplate issues of customary law including customary land tenure, it went further to say:

This Court, established in the Constitution, operates within the Australian legal system. It draws its legitimacy from that system. Self-evidently, it is not an institution of Aboriginal customary law. To the extent that native title is recognized and enforced in Australia by Australian law, this occurs because although not of the common law, native title is recognized by the common law as not inconsistent with its precepts. This does not mean that, within its own world, native title (or any other incidents of the customary laws of Australia's indigenous peoples) depends upon the common law for its legitimacy or content. To the extent that tide of history has not washed away the real observance of traditional customs, their legitimacy and content rest upon the activities and will of the indigenous people themselves.

The court thus refused to examine what customary, valid, repugnant and gentry would be in this case and held in favour of the WIKS.

The argument is hereby made that while MABO forms a strong inspiration for the resolution of indigenous land disputes, one should be ready to look beyond its hooks when it becomes necessary to trace the origins of the land because the means of the modern (or common law) court to trace the origins may not necessarily tie in with the means of the traditional (or customary) court to trace origins. For example, how can the common law court trace the spiritual link of indigenous peoples with a particular piece of land?

\subsection{Claim the African Commission's Decision in the Endorois Case}

In Communication No $276 / 2003^{58}$, the African Commission on human and Peoples' Rights had the opportunity to grapple with issues surrounding the land rights of indigenous peoples. The Complainants alleged violations resulting from the displacement of the Endorois community, an indigenous community, from their ancestral lands, the failure to adequately compensate them for the loss of their property, the disruption of the community's pastoral enterprise and violations of the right to practise their religion and culture, as well as the overall process of development of the Endorois people.

In an unprecedented ruling, after finding that the Respondent State had violated Articles 1, 8, 14, 17, 21 and 22 of the African Charter, the African Commis-

${ }^{58}$ Communication No 276/2003-Centre for Minority Rights Development (Kenya) and Minority Rights Group International on behalf of Endorois Welfare Council v Kenya. 
sion recommended inter alia that the Respondent State:

1) Recognise rights of ownership to the Endorois and Restitute Endorois ancestral land.

2) Ensure that the Endorois community has unrestricted access to Lake Bogoria and surrounding sites for religious and cultural rites and for grazing their cattle.

3) Pay adequate compensation to the community for all the loss suffered.

4) Pay royalties to the Endorois from existing economic activities and ensure that they benefit from employment possibilities within the Reserve...

This indicates that the right to land is increasingly taking centre stage in the intellectual and academic discourse of indigenous peoples rights and heralds a new consciousness and line of thinking when it comes to the recognition of those rights. Customary rights of ownership can no longer be relegated to the back in favour of the more modern common law rights of ownership.

\section{Conclusion}

The problem of the land rights of indigenous peoples has been present in legal discourse for several decades now. In the early years there was complete denial that such rights existed. Governments and political elites behaved as if they believed that the constitutional and legal rights of indigenous communities were fully respected. Indeed, such was their belief that they were oblivious of the fact that indigenous communities in their countries were the victims of the most severe and widespread forms of discrimination ${ }^{59}$. Indigenous rights were assimilated and confused with minority rights.

As multiculturalism became widely accepted throughout the world, many countries formally abandoned the policy of ethnic assimilation and acknowledged that their inhabitants were ethnically and culturally diverse. This shift in thinking partly accounted in what culminated in the adoption of the Declaration of the Rights of Indigenous Peoples in 2007.

The link between indigenous peoples' cultural values and their land cannot be gainsaid. Thus, in order to duly respect indigenous peoples' cultural and spiritual values, States must recognize their rights of ownership and possession over land they have traditionally occupied.

An important consequence of this recognition is that indigenous peoples have to henceforth enjoy the right of ownership over their lands. But as with most laws and conventions, implementation may be a problem and enforcement through the courts has never been the easiest thing to achieve.

One of the early and ground-breaking decisions on the issue is the MABO decision of the High Court of Australia. That locus classicus, be it as it may in its achievement in opening the doors for the recognition of indigenous land rights in Australia, is not without criticisms. It advocates for the unsevered and con-

${ }^{59} \mathrm{~J}$. Faundez "Access to Justice and Indigenous Communities in Latin America" (2010) in Y. Ghai and J. Cottrell (eds), Marginalized Communities and Access to Justice, London: Routledge at p. 4. 
tinuous link of the indigenous peoples with the land, which they claim, which in most instances has been lost due to acts independent of their will and consciousness.

In advocating for the application of the MABO decision in similar situations in Africa, some of the hooks of MABO have been examined in this paper and for it to become law, suggestions have been proposed on how to avoid them. The first is to use the 2007 Declaration on the Rights of Indigenous Peoples as a novel international instrument guaranteeing and providing for the enforcement of those rights, even though the declaration itself makes reference to continuous link thereby implicitly validating the terra nullius fallacy. To move from that, a total disregard of the "connection" and "valid acts" necessity is proposed on the one hand to enable that the courts seised of indigenous land claims to examine and adjudicate on the cultural and spiritual links of the peoples to the land they claims; and on the other hand, the application of the decisions in the Wiks (Australia) and Endorois (African Commission on Human and People's Rights) cases to resolve land claims by indigenous peoples, is proposed.

\section{Conflicts of Interest}

The author declares no conflicts of interest regarding the publication of this paper.

\section{References}

Anaya, J. S. (1996). Indigenous Peoples in International Law (2nd ed.). Oxford: Oxford University Press.

Burnham, P. (2000). Whose Forest? Whose Myth? Conceptualisation of Community Forests in Cameroon. In A. Abramson, \& D. Theodossopoulos (Eds.), Land, Law and Environment. Mythical Land, Legal Boundaries (p. 38). London: Pluto Press.

Comaroff, J., \& Comaroff, J. (2012). The Theory from the South: Or How Euro-America Is Evolving toward Africa. Boulder, CO: Paradigm Publishers.

https://doi.org/10.1080/00664677.2012.694169

Declaration of the Rights of Indigenous Peoples (2007).

Dlamini, J. The Organic Native? Reframing the Land Question in South Africa. Unpublished Manuscript.

Ehiedu Iweriebor, E. G. (2011). The Colonization of Africa. New York: Schomburg Center for Research in Black Culture.

http://exhibitions.nypl.org/africanaage/essay-colonization-of-africa.html

Elias, T. O. (1970). The Nature of African Customary Law Cited in Report and Recommendations by the Panel of Experts on the Development of Policy Regarding Land Ownership by Foreigners in South Africa.

Faundez, J. (2010). Access to Justice and Indigenous Communities in Latin America. In Y. Ghai, \& J. Cottrell (Eds.), Marginalized Communities and Access to Justice. London: Routledge.

Gibson, A. M. (1984). Philosophical, Legal, and Social Rationales for Appropriating the Tribal Estate, 1607 to 1980. American Indian Law Review, 12, 3-38.

https://doi.org/10.2307/20068248 
Kennedy, D. (2006). Three Globalizations of Law and Legal Thought: 1850-2000. In D. M. Trubek, \& A. Santos (Eds.), The New Law and Economic Development: A Critical Appraisal (pp. 19-73). New York: Cambridge University Press.

Mbembe, A. (2001). On the Post Colony. Oakland, CA: University of California Press.

McLuhan, T. C. (1971). Touch the Earth: A Self Portrait of Indian Existence; a Compilation of Indigenous Peoples Statements about the Land and Its Meaning.

Povinelli, E. (2002). The Cunning of Recognition: Indigenous Alterities and the Making of Australian Culturalism. Durham, NC: Duke University Press. https://doi.org/10.1215/9780822383673

Stone, J. (1966). Social Dimensions of Law and Justice. London: Stevens.

Sumner, W. G. (1906). Law and Social Change, Folkways. New York: Dover Publications.

Williams, R. A. (1990). The American Indian in Western Legal Thought. Oxford: Oxford University Press.

\section{Cases}

Case of Bakweri Land Claims Committee (BLCC) v. Cameroon, Communication (2014) No 260/2002, ACHPR 16th Extraordinary Session 20-29 July 2014.

Centre for Minority Rights Development (Kenya) and Minority Rights Group International on Behalf of Endorois Welfare Council v Kenya. Communication No 276/2003.

Communication No. R.6/24 (29 December 1977), U.N. Doc. Supp. No. 40 (A/36/40) at 166 (1981).

Hayes v. Northern Territory (1999).

Members of the Yorta Yorta Aboriginal Community v Victoria \& Ors [1998] FCA 1606 (1998).

The Members of the Yorta Yorta Aboriginal Community v. the State of Victoria (1998).

Wik Peoples v Queensland (Pastoral Leases Case) [1996] HCA 40; (1996) 187 CLR 1; (1996) 141 ALR 129; (1996) 71 ALJR 173 (23 December 1996). 